\title{
The anticarcinogenic potential of milk fat
}

\author{
Grażyna Cichosz ${ }^{1, \mathrm{~A}, \mathrm{D}, \mathrm{F} \oplus}{ }^{\oplus}$, Hanna Czeczot ${ }^{2, \mathrm{~B}, \mathrm{E}-\mathrm{F} \oplus}{ }^{\oplus}$, Marika Bielecka $^{1, \mathrm{~B}, \mathrm{E} \oplus}$ \\ ${ }^{1}$ Department of Dairy Science and Quality Management, University of Warmia and Mazury, Olsztyn, Poland \\ 2 Department of Biochemistry, Faculty of Medicine, Medical University, Warsaw, Poland \\ A - Research concept and design, B - Collection and/or assembly of data, C - Data analysis and interpretation, \\ $D$ - Writing the article, E - Critical revision of the article, F - Final approval of article
}

Cichosz G, Czeczot H, Bielecka M. The anticarcinogenic potential of milk fat. Ann Agric Environ Med. 2020; $27(4)$ : 512-518. doi: $10.26444 /$ aaem/116095

\begin{abstract}
Introduction and objective. The anticarcinogenic potential of milk fat can be attributed to its antioxidant, anti-inflammatory, immunostimulatory properties as well as the presence of compounds with antimutagenic effects. In view of the high incidence of cancer the aim of this article was to review the literature concerning the biological activity of milk fat components.

Brief description of the state of knowledge. Conjugated linoleic acid (CLA), coenzyme Q10, phospholipids, $\beta$-carotene, and vitamins A, D and E play an important role in the pro-oxidant/antioxidant homeostasis. The anti-inflammatory properties of milk fat can be attributed to the presence of phospholipids and short- and medium-chain saturated fatty acids. Conjugated linoleic acid has immunostimulatory properties, and it influences the proliferation and activity of lymphocytes and macrophages. Saturated (C10 and C12) and unsaturated (C18) fatty acids, as well as sphingolipids, exert bactericidal effects in the gastrointestinal tract. Vaccenic acid, CLA and sphingomyelin possess antimutagenic and anticarcinogenic properties. Butyric acid promotes the apoptosis of cancer cells in the liver, and delivers positive effects in the treatment of breast and colorectal cancer. Alkylglycerols activate macrophages, stimulate phagocytosis and, most importantly, the apoptosis of cancer cells.

Conclusions. The health benefits of milk fat are not fully exploited due to its low consumption. Therefore, only some epidemiological studies have shown a negative correlation between the consumption of high-fat dairy products and the incidence of cancer. More research is needed involving human clinical trials to allow a better understanding of the anticancer biochemistry related with milk fat compounds.
\end{abstract}

Key words

milk fat, antioxidant properties, immunostimulatory and anticancerogenic potential

\section{INTRODUCTION}

Milk fat has unique properties due to its specific fatty acid profile that fully meets the nutritional needs of humans, as well as the stereospecific structure of triglycerides which resembles that of human breast milk fat. Milk fat globules are coated with a phospholipid-protein layer which stabilizes the fat emulsion in the aqueous phase of milk, protects triglycerides against hydrolysis, and prevents the autoxidation of unsaturated fatty acids $[1,2]$.

All milk fat components, including saturated fatty acids (considered to exert atherogenic effects), are biologically active. The Western diet is deficient in highly active lipophilic antioxidants (CLA, phospholipids, coenzyme $\mathrm{Q}_{10}, \beta$-carotene, vitamins $A, D$ and $E$ ). Antioxidant deficiencies disrupt the pro-oxidant and antioxidant homeostasis, which leads to chronic inflammation and increases the risk of cancer.

The type of consumed fat significantly influences prooxidant/antioxidant homeostasis. In diets abundant in vegetable fats, the demand for antioxidants increases proportionally (logarithmically) to the content of polyunsaturated fatty acids (PUFAs) and the number of unsaturated bonds. In contrast, milk fat promotes antioxidant homeostasis and is a source of unique ingredients with documented anti-inflammatory and anticarcinogenic properties. Despite the above, the health-promoting

Address for correspondence: Marika Bielecka, Department of Dairy Science and Quality Management, University of Warmia and Mazury in Olsztyn, Poland E-mail: marika.bielecka@uwm.edu.pl

Received: 08.12.2019; accepted: 03.01.2020; first published: 25.02.2020 properties of milk fat have been discredited in the scientific community due to the high content of saturated fatty acids and cholesterol.

\section{OBJECTIVE}

In view of the high and steadily growing incidence of cancer, including in progressively younger ages, the aim of this article was to review the literature concerning the biological activity of milk fat components. The significance of milk fat components in cancer treatment is discussed.

Antioxidant potential of milk fat components. Milk fat is one of the most abundant sources of lipophilic antioxidants in the human diet. Conjugated linoleic acid (CLA) which is synthesized by ruminal microbiota from vaccenic acid (trans-11 octadecenoic acid) is the most active antioxidant in milk fat [3]. The CLA content of milk ranges from 2 $37 \mathrm{mg} / \mathrm{g}$ of fat, and is determined by cattle breed, diet, age of the animal, age, season (CLA content is higher in May, June and July), and processing parameters, such as pasteurization, duration and conditions of storage. Fermented dairy products are much more abundant in CLA than non-fermented products [4].

Conjugated linoleic acid includes 28 positional and geometric isomers. The isomers with the highest levels of biological activity are cis-9, trans-11 and trans-10, cis-12 isomers. The cis-9, trans-11 isomer is predominant in the CLA complex (75-95\%), and delivers health benefits on account 
of its very high antioxidant potential [5]. In vitro and in vivo studies have demonstrated that the cis-9, trans-11 isomer is more effective in protecting structural lipids against free radicals than $\alpha$-tocopherol, even at low concentrations $[6,7]$.

Dairy products are rich in carotenoids and vitamin A which prevent the oxidation of LDL-cholesterol and inhibit lipid peroxidation in tissues with low partial pressure of oxygen. $\beta$-carotene is a much more effective scavenger of singlet oxygen and lipid peroxides than vitamins $\mathrm{A}, \mathrm{E}$ and $\mathrm{C}$ $[8,9,10]$. Vitamin E, one of the key antioxidants in milk fat, and complements the antioxidant properties of vitamin $\mathrm{A}$ and its derivatives [1]. Dietary sources contain eight chemical forms of vitamin $E$, including four tocopherols $(\alpha, \beta, \gamma, \delta)$ and four tocotrienols $(\alpha, \beta, \gamma, \delta)$, where $\alpha$-tocopherol is the main biologically active form of vitamin $\mathrm{E}[12,13]$.

The above can be attributed to the fact that $\alpha$-tocopherol is activated at body temperature and that $\alpha$-tocopherol transfer protein ( $\alpha \mathrm{TTP})$, a specialist protein produced by the liver, specifically binds and transports only this form of tocopherol $[11,13]$.

Milk fat contains only a-tocopherol which, despite low concentrations $(13-30 \mu \mathrm{g} / \mathrm{g}$ fat $)$, effectively protects milk fat against auto-oxidation. The chemical structure of a-tocopherol, which comprises a chromanol ring (head) and an isoprene side chain (tail), makes it the most active lipophilic antioxidant in the human body. In lipid bilayers, the hydrophobic tail is inserted between hydrocarbon chains, whereas the polar head is exposed to a hydrophilic environment. Cell membranes and blood plasma lipoproteins a-tocopherol are protected against ROS by scavenging organic free radicals, terminating lipid peroxidation and extinguishing singlet oxygen. These reactions produce a relatively non-reactive tocopheryl radical which can interact with other free radicals, or undergo regeneration to the basic structure of vitamin $\mathrm{E}$ in the presence of a reduced form of coenzyme $\mathrm{Q}_{10}$ or vitamin C. Vitamin $\mathrm{E}$ also supports the activity of glutathione-dependent enzymes and interacts with selenium and sulfur-containing amino acids in cell membranes to prevent the peroxidation of structural phospholipids. It exerts a protective effect on vitamin A and regenerates $\beta$-carotene $[12,13,14]$. Vitamin E maintains the healthy structure and permeability of cell membranes, which is particularly important for cells and tissues most exposed to oxidative stress, such as erythrocytes and alveoli [15].

Coenzyme $\mathrm{Q}_{10}$, found mainly in butter $(7.1 \mathrm{mg} / \mathrm{kg})$ and ripened cheeses $(1.2-1.3 \mathrm{mg} / \mathrm{kg})$ [16], transports electrons in the respiratory chain and participates in the formation of ATP in cells [17]. Coenzyme $\mathrm{Q}_{10}$ is a highly active antioxidant, and ubiquino - its reduced form - protects cell membranes and LDL lipoproteins against peroxidation more effectively than $\alpha$-tocopherol and $\beta$-carotene. Ubiquinol prevents the initiation and propagation of peroxidation of polyunsaturated fatty acids in lipids and phospholipids in mitochondrial membranes. Coenzyme $\mathrm{Q}_{10}$ binds with proteins to stabilize mitochondrial membranes and guarantee their optimal fluidity. Ubiquinol enhances the antioxidant properties of vitamin $\mathrm{E}$ by participating in the regeneration of tocopherol radicals to tocopherol. Direct antioxidant effects in cells are induced by the reduced form of coenzyme $\mathrm{Q}_{10}$, whereas indirect effects are associated with vitamin E regeneration $[17,18]$. The content of different antioxidants in milk fat is generally low.

Despite the above, these compounds stimulate the endogenous antioxidant systems in the human body.
They prevent the oxidation of structural lipids by exerting pleiotropic and synergistic effects [19].

Immunostimulatory potential of milk fat components. Experimental evidence indicates that CLA influences the proliferation and activity of lymphocytes and macrophages, increases the cytotoxicity of T-cells and the phagocytic ability of leukocytes, and neutralizes bacterial endotoxins. It regulates eicosanoid transformations, modulates interleukin and leukotriene activity. The trans-10, c-12 isomer prevents the conversion of n-6 AA to $\mathrm{E}_{2}$ prostaglandins, thus inhibiting the production of proinflammatory cytokines [20].

A randomized trial revealed that diets supplemented with a combination of cis-9, trans-11 and trans-10, cis-12 CLA isomers at a 1:1 ratio ( $3 \mathrm{~g} /$ day for 12 weeks) increased IgA and IgM levels and decreased the concentration of IgE. The analyzed isomers also induced a decrease in the concentrations of proinflammatory cytokines (IL-1) and tumour necrosis factor-alpha (TNF- $\alpha$ ), and contributed to an increase in anti-inflammatory cytokine levels (IL-10) [21]. By modifying the fluidity and permeability of cell membranes, CLA exerts bacteriostatic and immunomodulatory effects, prevents hypertriglyceridaemia, and improves bone mineralization $[22,23,24]$.

Short-chain and medium-chain saturated fatty acids which are found in milk fat and are synthesized from fibre by gut microbiota also exert indirect immunomodulatory effects. Both short-chain and medium-chain SFAs induce the growth, maturation and differentiation of colonocytes, which contributes to the formation of healthy epithelial structure in the gastrointestinal tract [25]. They are absorbed in the small and large intestines, regulate water and electrolyte adsorption, and stimulate colonic motility and contractility. By controlling the blood flow, SFAs supply nutrients and regenerate colonic mucosa. Short-chain SFAs which are supplied with food and produced by probiotic lactic acid bacteria, play equally important roles in the regeneration of the intestinal epithelium They enhance the ionization of mineral compounds and increase their bioavailability [26].

Milk fat contains small amounts of PUFAs which are precursors of biologically active long-chain PUFAs. The ratio of n- 6 linoleic acid to $n-3$-linolenic acid in milk fat (3.5-5: 1) is optimal for health. The dietary n-6/n-3 PUFA ratio determines the fatty acid composition of membrane phospholipids.

The above contributes to the differentiation of eicosanoids produced by $n-6$ arachidonic acid (AA) and n-3 eicosapentaenoic acid (EPA). The transformation of n- 6 arachidonic acid leads to the production of proinflammatory and prothrombotic eicosanoids that weaken the immune system [27]. Excessive levels of n-6 PUFAs, which are found mostly in vegetable oils, increase the risk of inflammations that contribute to atherosclerosis, cancer and neurological disorders. Eicosanoids produced by n-3 EPA have anti-inflammatory, antithrombotic, anti-allergenic, immunostimulatory and anticarcinogenic properties. n-3 EPA is a competitive antagonist of n- 6 arachidonic acid, which decreases the ability of cells to synthesize proinflammatory eicosanoids from n-6 AA by $60-70 \%[28,29]$.

Vitamin A influences innate immunity by preserving the integrity of mucosal membranes, stimulating the synthesis of lysozyme and mucin, and enhancing the production of white blood cells. Vitamin A deficiency significantly 
weakens neutrophil activity, even if neutrophil counts are normal. Retinol, an active form of vitamin A, also influences macrophage counts and activity, and it enhances the production of TGF- $\beta$ which plays a role in wound healing. Beta-carotene supplementation ( $30 \mathrm{mg}$ /day) counteracted the weakening of the immune response in men exposed to UV radiation. Prolonged $\beta$-carotene supplementation increased lymphocyte counts and stimulated the activity of natural killer (NK) cells [30].

Vitamin E protects lymphocytes against the harmful effects of free radicals, and its concentration is higher in lymphocytes than in erythrocytes. $\alpha$-tocopherol inhibits protein kinase C which transduces signals from receptors to cytokines in monocytes and lymphocytes. $\alpha$-tocopherol also prevents activated macrophages from producing immunosuppressive agents such as $\mathrm{PGE}_{2}$ and hydrogen peroxide.

Vitamin $\mathrm{D}_{3}$ is responsible for the secretion of antibodies by $B$ cells and the secretion of cytokines by Th1 cells. It influences the induction of monocyte differentiation and inhibits the proliferation of T cells [31]. Defects in $1,25(\mathrm{OH})_{2} \mathrm{D}_{3}$ secretion by macrophages probably lead to autoimmunization. Vitamin $\mathrm{D}_{3}$ can inhibit neural tissue demyelination in multiple sclerosis and the degeneration of pancreatic $\beta$-cells $[32,33]$.

A diet rich in full-fat dairy products prevents pathogens from colonizing the gastrointestinal tract. Saturated fatty acids $\mathrm{C} 10$ and $\mathrm{C} 12$, unsaturated fatty acids $\mathrm{C} 18$, sphingolipids and lysosphingolipids were found to exert the greatest bactericidal effects in vitro [34, 35]. At a concentration of $100 \mathrm{mmol} \mathrm{L}^{-1}$, sphingosine reduced the counts of pathogenic bacteria [36]. Lysosphingomyelin effectively eliminated Campylobacter jejuni, Listeria monocytogenes and Clostridium perfringens, and it reduced the counts of E. coli and Salmonella enteritidis [36]. The phospholipids, proteins and enzymes that make up the milk fat globule membrane also effectively suppress the growth of Helicobacter pylori [37, 38].

Anticarcinogenic potential of milk fat components. The anticarcinogenic potential of unique milk fat components (CLA, vaccenic acid, phospholipids, including ether lipids and 13-methyltetradecanoic acid), and vitamins $\mathrm{A}_{2} \mathrm{D}_{3}$ and $\mathrm{K}_{2}$, can be attributed to their antioxidant, anti-inflammatory and immunostimulatory properties [39].

Conjugated linoleic acid delivers a host of health benefits by inhibiting the proliferation of tumour cells in all phases of carcinogenesis: initiation, promotion and progression. It exerts pleiotropic effects, which is why it is more effective than a combination of tocopherols and PUFAs (n-3) from fish and sea mammals. The supplementation of rat diets with $0.5 \%$ CLA inhibited lipid oxidation (decreased TBARS levels), and decreased cholesterol and triacylglycerol levels [40].

The supplementation of animal diets with $0.05-1.5 \%$ CLA inhibited the progression of chemically-induced skin, mammary gland, gastric and colorectal cancer. Oxidation of CLA in cancer cells probably stimulates the production of cytotoxic radicals. Conjugated linoleic acid also inhibits the synthesis of eicosanoids that stimulate the growth and division of cancer cells. Its antiproliferative effects have been confirmed in vitro and in studies of various cancer cell lines. Cell membranes containing CLA were found to be more resistant to mutagenic factors [6].

The antiproliferative activity of CLA has been confirmed in vitro and in studies of various cancer cell lines. The incorporation of CLA into cell membranes increases their resistance to mutagenic factors. Conjugated linoleic acid also inhibits DNA synthesis and angiogenesis $[6,41]$. In humans, the daily dose of CLA which effectively prevents cancer has been estimated at $3.5 \mathrm{~g}$, which is much higher than the amount of CLA in a typical diet (0.5-1.5 g) [42]. However, epidemiological research revealed that in countries with the highest consumption of ripened cheese, a rich source of CLA, breast cancer mortality rates were lower than in countries where ripened cheese was less popular [43].

Conjugated linoleic acid from milk fat exerts anticarcinogenic effects by entering into synergistic interactions with other compounds, including $\alpha$-tocopherol, $\beta$-carotene, vitamins $A$ and $D_{3}$, phospholipids, short-chain saturated fatty acids, vaccenic acid, coenzyme $Q_{10}$ and ether lipids [19]. Natural cis and trans isomers of vaccenic acid (C18:1) play a unique biological role in membrane phospholipids and glycolipids by promoting the adaptation of microorganisms and macroorganisms to the surrounding environment. These isomers also participate in signal transduction from the cytoplasm to cell membranes, and activate membrane enzymes and receptors which protect the host's cells and maintain cellular homeostasis. Vaccenic acid isomers significantly slowed down the proliferation of colorectal cancer cells in vitro, and the trans isomer was twice as effective as the cis isomer. The analyzed isomers preserved the healthy structure of cell membranes in the gastrointestinal tract $[44,45]$.

Carotenoids quench singlet oxygen and effectively protect DNA against oxidation. Beta-carotene intensifies the synthesis of IL-12 which stimulates the proliferation, activation and cytotoxicity of NK cells. These mechanisms prevent skin tumours caused by exposure to UV radiation, whereas vitamin A - in particular retinoic acid - prevents the onset of carcinogenesis, and $\beta$-carotene protects the body against the progression of cancer [46].

Plasma vitamin D levels higher than $30 \mathrm{ng} / \mathrm{ml}$ decrease the risk of lung, breast, intestinal and prostate cancer by $30-50 \%$. By inhibiting the proliferation and differentiation of cancer cells and inducing apoptosis, vitamin D prevents carcinogenesis and cancer metastasis [47].

Vitamin K2 (menaquinone) induces apoptosis [48]. Studies of brain, stomach and colon cancer cell lines have shown that vitamin $\mathrm{K} 2$ inhibits the cell cycle. It enhances the expression of the protein responsible for DNA degradation, thus suppressing repair processes in cancer cells. Recent research into bile duct cancer and leukemia has shown that vitamin $\mathrm{K} 2$ is capable of inducing autophagy. It also participates in oncosis, a form of cell death caused by ischemia, to which cancer cells are particularly susceptible [49]. Menoquinone interacts with vitamin $\mathrm{K} 3$ to inhibit angiogenesis which slows down the development of neoplastic cells [50]. Vitamin K2 modifies growth factors and their receptors by weakening their stimulatory effect on tumour initiation and progression [51]. By inducing oxidative stress without toxic consequences for tissue health, K2 contributes to the death of cancer cells [52].

Laboratory experiments and epidemiological research have demonstrated that vitamin K2 has immense potential for treating various types of cancer. Vitamin K2 inhibits the initiation, promotion and progression of human hepatocellular carcinoma cells [48]. In various types of lung cancer, including small-cell carcinoma, squamous- 
cell carcinoma and adenocarcinoma, vitamin $\mathrm{K} 2$ induces apoptosis by activating 'suicide' proteins [53]. A study of 11,000 male subjects has revealed that increased consumption of vitamin $\mathrm{K} 2$ can reduce the risk of prostate cancer by $35 \%$. The health benefits of vitamin K2 were most apparent in patients with advanced prostate cancer [54].

Milk phospholipids, in particular sphingomyelin (which is found in the membrane of milk fat globules), protect skin cells against UV radiation [55]. Sphingomyelin exerted chemopreventive or even chemotherapeutic effects in mice with chemically-induced colorectal cancer [56]. Sphingolipid digestion products, ceramides and sphingosines, influence the growth, differentiation and apoptosis of cells, in particular in the intestinal epithelium [57].

The health benefits of MFGM lipids, in particular in the treatment of colon cancer, have been recently confirmed [58]. Research into other cell types indicates that sphingolipids can prevent damage caused by $\gamma$ radiation and chemical compounds [59]. Due to the presence of long-chain SFAs in its structure, sphingomyelin is able to interact with cholesterol to create rigid domains known as lipid rafts, which compromises the survival of cancer cells and metastatic ability [60].

Milk fat phospholipids contain alkylglycerols and alkyl glycerophospholipids. Alkylglycerols activate macrophages: they increase the fluidity and responsiveness of cell membranes by mediating changes in surface receptors. These processes enable macrophages to secrete more than 60 substances that inhibit acute and chronic inflammations. Activated macrophages are capable of recognizing cancer cells. Alkylglycerols inhibit kinase $\mathrm{C}$ and cancer promotion. These potent antioxidants protect tissues against the toxic effects of hydroxyl radicals which are generated in large quantities during radiation therapy $[61,62]$.

13-methyltetradecanoic acid, a unique component of milk fat with an odd number of carbon atoms and a branched carbon chain, is capable of inducing the apoptosis of cancer cells $[2,63,64]$.

Controversy surrounding the anticarcinogenic potential of milk fat. All milk fat components have antimicrobial, anti-inflammatory and immunostimulating properties, and they exert protective effects on gastrointestinal and respiratory mucosa. The anticarcinogenic potential of CLA, vaccenic acid, phospholipids, 13-methyltetradecanoic acid, and vitamins $\mathrm{D}_{3}$ and $\mathrm{K}_{2}$ has also been documented.

Despite the above, the results of epidemiological studies comparing the incidence of three types of cancer in people consuming low-fat and high-fat dairy products are inconclusive, non-replicable and highly controversial $[65,66,67,68,69]$. Epidemiological studies have revealed potential correlations between the consumption of milk fat and the risk of bladder cancer, but the results are ambiguous and inconclusive [70]. In a cohort study of Dutch women, a positive correlation was found between the consumption of butter and full-fat milk and the risk of bladder cancer [71].

According to other studies, high consumption of milk fat containing high levels of SFAs and cholesterol enhances the production of endogenous estrogens, and contributes to the initiation and promotion of cancer. On the other hand, several epidemiological and cohort studies have shown that dietary milk fat does not increase the risk of breast cancer $[72,73,74]$.
In vitro experiments and animal studies have failed to provide convincing evidence that milk fat has carcinogenic properties. It should be noted that milk fat components, such as CLA, are renowned for their immunostimulatory and antioxidant potential. A meta-analysis has revealed that animal fats do not contribute to the risk of breast cancer [75]. Prospective studies have demonstrated that dairy products not only do not increase, but actually reduce the risk of breast cancer [76].

A study investigating the health status and diets of 64,904 Norwegian women revealed that overall consumption of dairy products, including milk, yogurt, various types of cheeses and ice-cream, is not correlated with the risk of breast cancer. Regular intake of cheese in the daily amount of $25 \mathrm{~g}$ minimized cancer risk by $50 \%$ in premenopausal women and by $20 \%$ in postmenopausal women [77]. High-fat dairy products are abundant in vitamins $\mathrm{D}_{3}$ and $\mathrm{K}_{2}$. Vitamin $\mathrm{D}$ regulates hormone levels and prevents the estrogen-induced proliferation of cancer cells by lowering progesterone and estradiol concentrations [78]. It has antiproliferative, proapoptotic and pro-differentiating effects on many types of neoplastic cells $[79,80]$. Vitamin D plays a very important role in preventing breast, prostate and colon cancer [81]. Vitamin $\mathrm{K}_{2}$ has considerable potential not only in the prevention, but also in the treatment of cancer $[53,54]$.

According to a review of epidemiological research conducted by Barrubés et al. (2018), the consumption of dairy products, including full-fat milk products, is not correlated with the risk of colorectal cancer (CRC) [82]. A meta-analysis of the relevant literature did not reveal any correlations between the consumption of milk with different fat content and the risk of breast cancer [83]. However, the risk of aggressive prostate cancer was $74 \%$ higher in men who consumed the largest quantities of whole milk relative to subjects who did not consume whole milk [84]. Despite the fact that high consumption of dairy products has been linked with the risk of prostate cancer, the accumulated evidence is ambiguous, mainly due to statistical inconsistency [85].

The discrepancy between the results of research studies investigating the correlations between the consumption of dairy products and the risk of cancer could be attributed to the quality of the milk. Milk from cows affected by mastitis is characterized by high concentrations of inflammatory cytokines, eicosanoids and acute phase proteins (produced by somatic cells). These parameters are correlated with higher levels of transforming growth factors (TGF) and insulin-like growth factor IGF-1, which plays a key role in the regulation of cell proliferation, differentiation and apoptosis [86]. The concentration of IGF-1 is several-fold higher in the milk of cows simulated with bovine somatotropin (rbGh) which radically increases milk yield and was approved for use in the USA in 1994 [87]. High blood levels of IGF-1 increase the risk of prostate and breast cancer $[84,88,89]$. For this reason, the use of rbGh in dairy cattle has been banned in all EU member states, Canada, Australia, New Zealand and Japan.

In addition to components with documented anticarcinogenic potential, milk fat may contains compounds that contribute to the development of cancer, such as aflatoxins, pesticides and estrogens [90, 91, 92, 93]. The composition of milk fat is also determined by animal nutrition. The synthesis of bioactive compounds increased 35 -fold in the milk of grass-fed cows (due to the predominance 
of cellulolytic bacteria in the rumen) than in the milk of cows fed TMR throughout the year $[94,95]$. It should also be noted that only the milk of grass-fed cows supplies the daily CLA dose that is effective in cancer prevention.

Carcinogenesis is a complex process with many etiologic agents, which is why the influence of one or several nutrients on neoplasia is difficult to confirm or rule out with certainty. The presence of correlations between selected dietary components and increased risk of cancer does not constitute sufficient scientific evidence, especially since most nutrients exert pleiotropic effects.

The above can explain the different and often contradictory results of studies investigating the significance of milk fat in cancer prevention.

\section{CONCULSION}

Milk fat is a rich source of lipophilic antioxidants (conjugated linoleic acid - CLA, phospholipids, vitamins A, E and $\mathrm{D}_{3}$ ). These compounds occur in small quantities, but they effectively prevent oxidation processes in the human body due to their high thermostability and pleiotropic and synergistic interactions.

Many milk fat components deliver immunostimulatory effects. Phospholipids and long-chain saturated fatty acids have antiviral and antimicrobial properties. Short-chain and medium-chain SFAs regulate water and electrolyte adsorption, they contribute to the regeneration of the intestinal epithelium by promoting the growth, maturation and differentiation of colonocytes, and enhance the ionization and bioavailability of minerals. Eicosanoids derived from a-linolenic acid (n-3), as well as lipophilic vitamins, have anti-inflammatory properties. Conjugated linoleic acid directly contributes to an increase in IgA and IgM levels and a decrease in IgE levels and proinflammatory agents.

The unique components of milk fat (CLA, vaccenic acid, phospholipids, including ether lipids, 13-methyltetradecanoid acid) and vitamins $\mathrm{A}_{2} \mathrm{D}_{3}$ and $\mathrm{K}_{2}$ have antioxidant, antiinflammatory and immunostimulating properties and exert anticarcinogenic effects. However, milk fat can contain persistent organic pollutants (polychlorinated biphenyls, dioxins and pesticides) with mutagenic and carcinogenic effects.

Despite the above, most of the reviewed epidemiological studies did not demonstrate correlations between the consumption of full-fat dairy products and increased incidence of cancer.

Low consumption of milk fat leads to a deficiency of lipophilic antioxidants in the human diet. This disrupts the pro-oxidant/antioxidant homeostasis, leads to chronic inflammations and promotes the development and progression of cancer. Hydrophilic antioxidants (present in fruit and vegetables) are not highly effective in the lipophilic environment of the human body, i.e. inside cell membranes and plasma lipoproteins. In diets rich in vegetable oils, the demand for lipophilic antioxidants increases logarithmically and proportionally to the quantity of polyunsaturated fatty acids.

These observations indicate that the elimination of milk fat from the human diet not only detracts from cancer prevention, but increases the risk of carcinogenesis.

\section{REFERENCES}

1. Lindmark-Månsson $\mathrm{H}$, Akesson B. Antioxidative factors in milk. Br J Nutr. 2000; 84 (Suppl 1): 103-110. https://doi.org/10.1017/ s0007114500002324

2. Parodi PW. Anti-cancer agents in milkfat. Austr J Dairy Technol. 2003; 58(2): 114-118.

3. Griinari JM, Corl BA, Lacy SH, Chouinard PY, Nurmela KVV, Bauman DE. Conjugated linoleic acid is synthesized endogenously in lactating dairy cows by $\Delta 9$-desaturase. J Nutr. 2000; 130(9): 2285-2291. https:// doi.org/10.1093/jn/130.9.2285

4. Gutiérrez LF. Conjugated Linoleic Acid in milk and fermented milks: variation and effects of the technological processes. Vitae, 2016; 23(2): 134-145. http://dx.doi.org/10.17533/udea.vitae.v23n2a06

5. Kowalska M, Cichosz G. Dairy products - the best source of CLA. Bromat Chem Toksykol. 2013; 46(1): 1-12.

6. Kelley NS, Hubbard NE, Erickson KL. Conjugated linoleic acid isomers and cancer. J Nutr. 2007; 137: 2599-2607. https://doi.org/10.1093/ jn/137.12.2599

7. Bhattacharya A, Banu J, Rahman M, Causey J, Fernandes G. Biological effects of conjugated linoleic acids in health and disease. J Nutr Biochem. 2006; 17: 789-810. https://doi.org/10.1016/j.jnutbio.2006.02.009

8. Sies H, Stahl W, Sundguist AR. Antioxidant functions of vitamins. Vitamin E and C, beta-carotene and other carotenoids. Ann N.Y. Acad Sci. 1992; 669: 7-20. https://doi.org/10.1111/j.1749-6632.1992.tb17085.x

9. van den Berg H, Faulks R, Fernando-Granado H, Hirschberg J, Olmedilla B, Sandmann G, et al. The potential for the improvement of carotenoid levels in foods and the likely systemic effects. J Sci Food Agr. 2000; 80: 880-912. https://doi.org/10.1002/(SICI)10970010(20000515)80:7\%3C880::AID-JSFA646\%3E3.0.CO;2-1

10. Rahman K. Studies on free radicals, antioxidants, and co-factors. Clin Interv Aging. 2007; 2: 219-236. https://www.ncbi.nlm.nih.gov/pmc/ articles/PMC2684512/

11. Hosomi A, Arita M, Sato Y, Kiyose C. Affinity for a-tocopherol transfer protein as a determinant of the biological activities of vitamin $\mathrm{E}$ analogs. FEBS Lett. 1997; 409: 105-108. https://doi.org/10.1016/s00145793(97)00499-7

12. Cichosz G, Czeczot H, Amroziak A, Bielecka MM. Natural antioxidants in milk and dairy products. Int J Dairy Technol. 2017; 70(2): 165-178. https://doi.org/10.1111/1471-0307.12359

13. Schneider C. Review: chemistry and biology of vitamin E, Mol Nutr Food Res. 2005; 49: 7-30. https://doi.org/10.1002/mnfr.200400049

14. Wang X, Quinn PJ. Vitamin E and its function in membrans. Prog Lipid Res. 1999; 38: 309-336.

15. Gohil K, Oommen S, Vasu VT, Aung HH, Cross CE. Tocopherol transfer protein deficiency modifies nuclear receptor transcriptional networks in lungs: modulation by cigarette smoke in vivo. Mol Aspects Med. 2007; 28: 435-480. https://doi.org/10.1016/j.mam.2007.02.004

16. Pravst I, Zmitek K, Zmitek J. Coenzyme Q10 contents in foods and fortification strategies. Crit Rev Food Sci Nutr. 2010; 50(4): 269-280. https://doi.org/10.1080/10408390902773037

17. Overvad K, Diamant B, Holm L. Coenzyme $Q_{10}$ in health and disease, Eur J Clin Nutr. 1999; 53(10): 74-70. https://doi.org/10.1038/ sj.ejcn. 1600880

18. Janicki B, Buzala M. Rola koenzymu Q10 w organizmie ludzi i zwierząt. Med Wet. 2012; 68(04): 214-217.

19. Cichosz G, Czeczot H. Milk fat - source of antioxidants in human diet. Bromat Chem Toksykol. 2011; 44(1): 8-16.

20. O'shea M, Bassaganya-Riera J, Mohede IC. Immunomodulatory properties of conjugated linoleic acid. Am J Clin Nutr. 2004; 79(6): 1199S-1206S. https://doi.org/10.1093/ajcn/79.6.1199S

21. Song HJ, Grant I, Rotondo D, Mohede I, Sattar N, Heys SD, et al. Effect of CLA supplementation on immune function in young healthy volunteers. Eur J Clin Nutr. 2005; 59: 508-517. https://doi.org/10.1038/ sj.ejcn.1602102

22. Belury MA. Inhibition of carcinogenesis by conjugated linoleic acid: Potential mechanisms of action. J Nutr. 2002; 132: 2995-2998. https:// doi.org/10.1093/jn/131.10.2995

23. Belury MA. Dietary conjugated linoleic acid in health: physiological effects and mechanisms of 316 action. Ann Reviews Nut. 2002; 22(1): 505-531. https://doi.org/10.1146/annurev.nutr.22.021302.121842

24. McGuire MA, McGuire MK. Conjugated linoleic acid (CLA): A ruminant fatty acid with beneficial effects on human health. J Anim Sci. 2000; 77(E-Suppl): 1-8. https://doi.org/10.2527/ jas2000.00218812007700ES0033x

25. Roediger WEW. The place of short-chain fatty acids in colonocyte metabolism in health and ulcerative colitis: the impraired colonocyte 
barrier. In: Cummings JH, Rombeau JL, Sakata T, editors Physiological and clinical aspects of short-chain fatty acids, Cambridge, Cambridge University Press. 1995. p. 337-351.

26. Tan J, McKenzie C, Potamitis M, Thorburn AN, Mackay CR, Macia L. The role of short-chain fatty acids in health and disease. Advances Immunol. 2014; 121: 91-119. https://doi.org/10.1016/B978-0-12-8001004.00003-9

27. Das UN. Essential fatty acids: biochemistry, physiology and pathology. Biotechnol J. 2006; 1(4): 420-439. https://doi.org/10.1002/ biot. 200600012

28. Rose DP; Connoly JM. Regulation of tumor aniogenesis by dietary fatty acids and eicosanoids. Nutr Cancer. 2003; 37(2): 119-127. https://doi. org/10.1207/S15327914NC372_1

29. Lavie CJ, Milani RV, Mehra MR, Ventura HO. Omega-3 polyunsaturated fatty acids and cardiovascular diseases. J Am Coll Cardiol. 2009; 54 (7): 585-594. https://doi.org/10.1016/j.jacc.2009.02.084

30. Krzysik M, Biernat J, Grajeta H. The Influence of Nutrients on Immune System Functioning - Part I. Immunomodulatory Effects of Fatty Acids on the Human Body. Adv Clin Exp Med. 2007; 16(1): 123-133.

31. Wang J, Lv S, Chen G, Gao C, He J, Zhong H, Xu Y. Meta-analysis of the association between vitamin $\mathrm{D}$ and autoimmune thyroid disease. Nutrients. 2015; 7(4): 2485-2498. https://doi.org/10.3390/nu7042485

32. Mowry EM, Waubant E, McCulloch CE, Okuda DT, Evangelista AA, Lincoln RR, et al. Vitamin D status predicts new brain magnetic resonance imaging activity in multiple sclerosis. Ann Neurol. 2012; 72(2): 234-240. https://doi.org/10.1002/ana.23591

33. He D, Wang Y, Liu R, He A, Li S, Fu X, Zhou Z. 1, $25(\mathrm{OH}) 2 \mathrm{D} 3$ Activates Autophagy to Protect against Oxidative Damage of INS-1 Pancreatic Beta Cells. Biol Pharm Bull. 2019; 42(4): 561-567. https:// doi.org/10.1248/bpb.b18-00395

34. Sprong RC, Hulstein MFE, Meer van der R. Bovine milk fat components inhibit food-borne pathogens. Int Dairy J. 2002; 12: 209-215. https:// doi.org/10.1016/S0958-6946(01)00139-X

35. Snow DR, Ward RE, Olsen A, Jimenez-Flores R, Hintze KJ. Membranerich milk fat diet provides protection against gastrointestinal leakiness in mice treated with lipopolysaccharide. J Dairy Sci. 2011; 94: 22012212. https://doi.org/10.3168/jds.2010-3886

36. Sprong RC, Hulstein MFE, van der Meer R. Bactericidal activities of milk lipids. Antimicrob Agents Ch. 2001; 45: 1298-1301. https://doi. org/10.1128/AAC.45.4.1298-1301.2001

37. Wang X, Hirmo S, Willen R, Wadström T. Inhibition of Helicobacter pylori infection by bovine milk glycoconjugates in a BALB/cA mouse model. J Med Microbiol, 2001; 50, 5: 430-435. https://doi. org/10.1099/0022-1317-50-5-430

38. Matsumoto M, Hara K, Kimata H, Benno Y, Shimamoto C. Exfoliation of Helicobacter pylori from gastric mucin by glycopolypeptides from buttermilk. J Dairy Sci. 2005; 88(1): 49-54. https://doi.org/10.3168/jds. S0022-0302(05)72661-8

39. Cichosz G, Czeczot H. Tłuszcz mlekowy w profilaktyce chorób nowotworowych. Pol Merk Lek. 2012; 33: 168-172.

40. Kim HK, Kim SR, Ahn JY, Cho IJ, Yoon CS, Ha TY. Dietary conjugated linoleic acid reduces lipid peroxidation by increasing oxidative stability in rats. J Nutr Sci Vitaminol. 2005; 51: 8-15. https://doi.org/10.3177/ jnsv. 51.8

41. Lee KW, Lee HJ, Chom HY, Kim YJ. Role of the conjugated linoleic acid inthe prevention of cancer. Crit Rev Food Sci Nutr. 2005; 45(2): 135-144. https://doi.org/10.1080/10408690490911800

42. Varga-Visi É, Mándoki Z, Csapó J. Increase of conjugated linoleic acid content of dairy products by adding sunfl ower oil. Acta Univ Sapientiae Aliment. 2009; 2(2): 287-293.

43. Białek A, Tokarz A. Dietary sources and beneficial health effects of conjugated linoleic acids (CLA). Biul. Wydz. Farm. WUM. 2009; 1: 1-12.

44. Blewett HJ, Gerdung CA, Ruth MR, Proctor SD, Field CJ. Vaccenic acid favourably alters immune function in obese JCR:LA-cp rats. Br J Nutr. 2009; 102(4): 526-536. https://doi.org/10.1017/S0007114509231722

45. Lim JN, Oh JJ, Wang T, Lee JS, Kim SH, Kim YJ, et al. Trans-11 18:1 vaccenic acid (TVA) has a direct anti-carcinogenic effect on MCF-7 human mammary adenocarcinoma cells. Nutr. 2014; 6: 627-636. https:// dx.doi.org/10.3390\%2Fnu6020627

46. Palozza P, Krinsky N. Beta-caroten and alpha-tocopherol are synergistic antioxidants. Arch Biochem Piophys. 1992; 15: 184-187. https://doi. org/10.1016/0003-9861(92)90658-j

47. Edwards BJ. Anticancer effects of Vitamin D. Am J Hematol/Oncol. $2015 ; 11(10): 26-33$

48. Xv F, Chen J, Duan L, Li S. Research progress on the anticancer effects of vitamin K2. Oncol Let. 2018; 15(6): 8926-8934. https://dx.doi. org/10.3892\%2Fol.2018.8502
49. Scott GK, Atsriku C, Kaminker P, Held J, Gibson B, Baldwin MA, et al. Vitamin K3 (menadione)-induced oncosis associated with keratin 8 phosphorylation and histone $\mathrm{H} 3$ arylation. Mol Pharmacol. 2005; 68(3): 606-615. https://doi.org/10.1124/mol.105.013474

50. Yoshiji H, Kuriyama S, Noguchi R, Yoshii J, Ikenaka Y, Yanase K, et al. Combination of vitamin $\mathrm{K} 2$ and the angiotensin-converting enzyme inhibitor, perindopril, attenuates the liver enzyme-altered preneoplastic lesions in rats via angiogenesis suppression. J Hepatol. 2005; 42(5): 687-693. https://doi.org/10.1016/j.jhep.2004.12.025

51. Yamamoto T, Nakamura H, Liu W, Cao K, Yoshikawa S, Enomoto $\mathrm{H}$, et al. Involvement of hepatoma-derived growth factor in the growth inhibition of hepatocellular carcinoma cells by vitamin $\mathrm{K}(2)$. J Gastroenterol. 2009; 44(3): 228-235. https://doi.org/10.1007/s00535008-2304-4

52. Verrax J, Taper H, Buc Calderon P. Targeting cancer cells by an oxidantbased therapy. Curr Mol Pharmacol. 2008; 1(1): 80-92.

53. Yoshida T, Miyazawa K, Kasuga I, Yokoyama T, Minemura K, Ustumi $\mathrm{K}$, et al. Apoptosis induction of vitamin $\mathrm{K} 2$ in lung carcinoma cell lines: the possibility of vitamin K2 therapy for lung cancer. Int J Oncol. 2003; 23(3): 627-632. https://doi.org/10.3892/ijo.23.3.627

54. Nimptsch K, Rohrmann S, Linseisen J. Dietary intake of vitamin K and risk of prostate cancer in the Heidelberg cohort of the European Prospective Investigation into Cancer and Nutrition (EPIC-Heidelberg). Am J Clin. Nutr. 2008; 87(4): 985-992. https://doi.org/10.1093/ ajen/87.4.985

55. Russell A, Laubscher A, Jimenez-Flores R, Laihom LH. Investigating the protective properties of milk phospholipids against ultraviolet light exposure in a skin equivalent model. Proc. SPIE. 2010; 75692Z-75692Z:9. https://doi.org/10.1117/12.845803

56. Lemonnier LA, Dillehay DL, Vespremi MJ, Abrams J, Brody E, Schmelz, EM. Sphingomyelin in the suppression of colon tumors: Prevention versus intervention. Arch Biochem Biophys. 2003; 419: 129-138. https:// doi.org/10.1016/j.abb.2003.08.023

57. Duan RD, Nilsson A. Metabolism of sphingolipids in the gut and its relation to inflammation and cancer development. Prog Lipid Res. 2009; 48: 62-72. https://doi.org/10.1124/mol.105.013474

58. Kuchta AM, Kelly PM, Stanton C, Devery RA. Milk fat globule membrane-A source of polar lipids for colon health? A review. Int J Dairy Technol. 2012; 65: 315-333. https://doi.org/10.1111/j.14710307.2011.00759.x

59. Vesper H, Schmelz EM, Nikolova-Karakashian MN, Dillehay DL, Lynch DV, Merrill AH. Sphingolipids in food and the emerging importance of sphingolipids to nutrition. J Nutr. 1999; 129: 1239-1250. https://doi. org/10.1093/jn/129.7.1239

60. Küllenberg D, Taylor LA, Schneider M, Massing U. Health effects of dietary phospholipids. Lipids Health Dis. 2012; 11: 1-16. https://doi. org/10.1186/1476-511X-11-3

61. Melvyn R, Werbach MD. Alkyloglycerols and Cancer. J Ortho Med. 1994; 9(2): 95-102.

62. Krotkiewski M, Przybyszewska M, Janik P. Cytostatic and cytotoxic effects of alkyloglycerols (Ecomer). Med Sci Monit. 2003; 9(11): 131-135.

63. Wongtangtintharn, S, Oku H, Iwasaki, H, Toda T. Effect of branchedchain fatty acids on fatty acid biosynthesis of human breast cancer cells. J Nutr Sci Vitaminol. 2004; 50: 137-143. https://doi.org/10.3177/ jnsv. 50.137

64. Yang Z, Liu S, Chen X, Chen H, Huang M, Zheng J. Induction of apoptotic cell death and in vivo growth inhibition of human cancer cells by a saturated branched-chain fatty acid, 13-methyltetradecanoic acid. Cancer Res. 2000; 60: 505-509.

65. Abbas S, Linseisen J, Chang-Claude J. Dietary vitamin D and calcium intake and premenopausal breast cancer risk in a German case-control study. Nutr Cancer. 2007; 59: 54-61. https://doi. org/10.1080/01635580701390223

66. Dal Maso L, Zucchetto A, Talamini R, Serraino D, Stocco CF, Vercelli $\mathrm{M}$, et al. Effect of obesity and other lifestyle factors on mortality in women with breast cancer. Int J Cancer. 2008; 123(9): 2188-2194. https://doi.org/10.1002/ijc. 23747

67. Pala V, Krogh V, Berrino F, Sieri S, Grioni S, Tjønneland A, et al. Meat, eggs, dairy products, and risk of breast cancer in the European Prospective Investigation into Cancer and Nutrition (EPIC) cohort. Am J Clin Nutr. 2009; 90: 602-612. https://doi.org/10.3945/ajcn.2008.27173

68. Chen P, Hu P, Xie D, Qin Y, Wang F, Wang H. Meta-analysis of vitamin $\mathrm{D}$, calcium and the prevention of breast cancer. Breast Cancer Res Treat. 2010; 121: 469-477. https://doi.org/10.1080/07315724.1999.10718903

69. Dong JY, Zhang L, He K, Qin LQ. Dairy consumption and risk of breast cancer: a meta-analysis of prospective cohort studies. Breast Cancer Res Treat. 2011; 127(1): 23-31. https://doi.org/10.1007/s10549-011-1467-5 
70. Mao QQ, Dai Y, Lin YW, Qin J, Xie LP, Zheng XY. Milk consumption and bladder cancer risk: A meta-analysis of published epidemiological studies. Nutr Cancer. 2011; 63: 1263-1271. https://doi.org/10.1080/01 635581.2011.614716

71. Keszei AP, Schouten LJ, Goldbohm RA, van den Brandt PA. Dairy intake and the risk of bladder cancer in the Netherlands Cohort Study on Diet and Cancer. Am J Epidemiol. 2010; 171: 436-446. https://doi. org/10.1093/aje/kwp399

72. Holmes MD, Pollak MN, Willett WC, Hankinson SE. Dietary correlates of plasma insulin-like growth factor I and insulin-like growth factor binding protein 3 concentrations. Cancer Epidemiol Biomarkers Prev. 2002; 11: 852-861.

73. Wu AH, Pike MC, Stram DO. Meta-analysis: dietary fat intake, serum estrogen levels, and the risk of breast cancer. J Natl Cancer Inst. 1999; 91: 529-534. https://doi.org/10.1093/jnci/91.6.529

74. Lee MM, Lin SS. Dietary fat and breast cancer. Ann Rev Nutr. 2000 20: 221-248. https://doi.org/10.1146/annurev.nutr.20.1.221

75. Alexander DD, Morimoto LM, Mink PJ, Lowe KA. Summary and meta-analysis of prospective studies of animal fat intake and breast cancer. Nutr Res Rev. 2010; 23: 169-179. https://doi.org/10.1017/ S095442241000003X

76. Dong JY, Zhang L, He K, Qin LQ. Dairy consumption and risk of breast cancer: a meta-analysis of prospective cohort studies. Breast Cancer Res Treat. 2011; 127(1): 23-31. https://doi.org/10.1007/s10549-011-1467-5

77. Hjartåker A, Thoresen M, Engeset D, Lund E. Dairy consumption and calcium intake and risk of breast cancer in a prospective cohort: the Norwegian Women and Cancer study. Cancer Causes Control. 2010; 21: 1875-1885. https://doi.org/10.1007/s10552-010-9615-5

78. Knight JA, Wong J, Blackmore KM, Raboud JM, Vieth R. Vitamin D association with estradiol and progesterone in young women. Cancer Causes Control. 2010; 21: 479-483. https://doi.org/10.1007/s10552 009-9466-0

79. Krishnan AV, Feldman D. Mechanisms of the anti-cancer and antiinflammatory actions of vitamin D. Annu Rev Pharmacol Toxicol. 2011; 51: 311-336. https://www.ncbi.nlm.nih.gov/pubmed/20936945

80. Rohan TE, Negassa A, Chlebowski RT, Ceria-Ulep CD, Cochrane $\mathrm{BB}$, Lane DS. A randomized controlled trial of calcium plus vitamin $\mathrm{D}$ supplementation and risk of benign proliferative breast disease. Breast Cancer Res Treat. 2009; 116: 339-350. https://doi.org/10.1007/ s10549-008-0213-0

81. Gandini S, Boniol M, Haukka J, Byrnes G, Cox B, Sneyd MJ, et al. Metaanalysis of observational studies of serum 25-hydroxyvitamin D levels and colorectal, breast and prostate cancer and colorectal adenoma. Int J Cancer. 2011; 128: 1414-1424. https://doi.org/10.1002/ijc.25439

82. Barrubés L, Babio N, Becerra-Tomás N, Rosique-Esteban N, SalasSalvadó J. Association Between Dairy Product Consumption and Colorectal Cancer Risk in Adults: A Systematic Review and MetaAnalysis of Epidemiologic Studies. Adv Nutr. 2018; 10(suppl_2): 190 211. https://doi.org/10.1093/advances/nmy114
83. Chen L, Li M, Li H. Milk and yogurt intake and breast cancer risk: A meta-analysis. Medicine 2019; 98(12): e14900. http://dx.doi. org//10.1097/MD.0000000000014900

84. Steck SE, Omofuma OO, Su LJ, Maise AA, Woloszynska-Read A, Johnson CJ, Zhang $\mathrm{H}$, et al. Calcium, magnesium, and whole-milk intakes and high-aggressive prostate cancer in the North CarolinaLouisiana Prostate Cancer Project (PCaP). Am J Clin Nutr. 2018; 107, 5: 799-807. https://doi.org/10.1093/ajcn/nqy037

85. López-Plaza B, Bermejo LM, Santurino C, Cavero-Redondo I, ÁlvarezBueno C, Gómez-Candela C. Milk and Dairy Product Consumption and Prostate Cancer Risk and Mortality: An Overview of Systematic Reviews and Meta-analyses. Adv Nutr. 2019; 10(suppl_2): S212-S223. https://doi.org/10.1093/advances/nmz014

86. Bannerman DD. Pathogen-dependent induction of cytokines and other soluble inflammatory mediators during intramammary infection of dairy cows. J Anim Sci. 2009; 87(suppl_13): 10-25. https://doi. org/10.2527/jas.2008-1187

87. Collier RJ, Miller MA, McLaughlin CL, Johnson HD, Baile CA. Effects of recombinant bovine somatotropin (rbST) and season on plasma and milk insulin-like growth factors I (IGF-I) and II (IGF-II) in lactating dairy cows. Domest Anim Endocrin. 2008; 35(1): 16-23. https://doi. org/10.1016/j.domaniend.2008.01.003

88. Christopoulos PF, Msaouel P, Koutsilieris M. The role of the insulinlike growth factor-1 system in breast cancer. Mol Cancer. 2015; 14(1) 43. https://doi.org/10.1186/s12943-015-0291-7

89. Harrison S, Lennon R, Holly J, Higgins JP, Gardner M, Perks C. et al. Does milk intake promote prostate cancer initiation or progression via effects on insulin-like growth factors (IGFs)? A systematic review and meta-analysis. Cancer Causes Control. 2017; 28(6): 497-5.

90. Moss MO. Risk assessment for aflatoxins in foodstuffs. Int. Biodeterior Biodegrd. 2002; 50: 137-142. https://doi.org/10.1016/S09648305(02)00078-1

91. Parodi PW. Impact of cows' milk estrogen on cancer risk. Int Dairy J. 2012; 22: 3-14. https://doi.org/10.1016/j.idairyj.2011.08.006

92. Moorman PG, Terry PD. Consumption of dairy products and the risk of breast cancer: a review of the literature. Am J Clin Nutr. 2004; 80: 5-14. https://doi.org/10.1093/ajcn/80.1.5

93. Qin LQ, Wang PY, Kaneko T, Hoshi K, Sato A. Estrogen: one of the risk factors in milk for prostate cancer. Med Hypotheses. 2004; 62: 133-142. https://doi.org/10.1016/s0306-9877(03)00295-0

94. Vlaeminck B, Fievez V, Cabrita ARJ, Fonseca AJM, Dewhurst RJ. Factors affecting odd- and branched-chain fatty acids in milk: A review. Anim Feed Sci Technol. 2006; 131: 389-417. https://doi.org/10.1016/j. anifeedsci.2006.06.017

95. Krzyżewski J, Strzalkowska N, Bagnicka E, Jozwik A, Horbanczuk JO. Effects of Antioxidants in Fat Contained in Bulky Forages on Cows' Milk Quality. Żywn. Nauk, Technol Jakość. 2012; 19: 35-45. 